\title{
What Heritage Tells Us About the Turkish State and Turkish Society
}

Également disponible en version française

\section{Muriel Girard}

Translator. Adrian Morfee

\section{(2) OpenEdition \\ Journals}

Electronic version

URL: http://journals.openedition.org/ejts/5227

DOI: $10.4000 /$ ejts.5227

ISSN: $1773-0546$

Publisher

EJTS

Electronic reference

Muriel Girard, « What Heritage Tells Us About the Turkish State and Turkish Society », European Journal of Turkish Studies [Online], Complete List, Online since 26 June 2015, connection on 19 February 2020. URL : http://journals.openedition.org/ejts/5227 ; DOI : 10.4000/ejts.5227

This text was automatically generated on 19 February 2020

(c) Some rights reserved / Creative Commons license 


\title{
What Heritage Tells Us About the Turkish State and Turkish Society
}

\author{
Également disponible en version française
}

\section{Muriel Girard}

Translation : Adrian Morfee

\section{EDITOR'S NOTE}

Version originale française : https://ejts.revues.org/5040

I wish to extend my special thanks to Clémence Scalbert-Yücel (Associate Research Fellow at the IFEA) for her support and active involvement in drawing up this special issue for the EJTS, together with Isabelle Gilles (Digital Publishing Officer at the IFEA) and Kerrie Bramhall for their help with the editorial work. I also wish to express my gratitude to the members of the editorial board and to the readers for the time and energy they have invested in this project, and without whom this issue would not have been possible, and to thank the authors.

1 Present-day Turkey is home to a proliferation of heritage productions, including local history initiatives, museums, urban schemes, and so on. ${ }^{1}$ This involves a large number of actors, many different identities demands, and a variety of scales (ranging from the local and national to the transnational and the international). This special issue seeks to study the dynamics at work within this heritagization, the actors involved, and the issues at stake. More specifically, it explores the theme of heritage in Turkey by focusing on the relationship between heritage and nation-building. The purpose is to approach this question by looking, firstly, at heritage as a process and form of social construction, and, secondly, at the heritage concepts of the actors involved, be they professionals or non-specialists.

Whilst such an approach is now fairly standard within the field of heritage studies, especially in French, ${ }^{2}$ it has hitherto been but little applied to Turkey. Research into built and urban heritage has to date been dominated by architects and historians of architecture (Pérouse, 2011), and tends to privilege the study of heritage objects (Ipek 
Tureli makes a similar observation in this issue). Work in the human and social sciences is, however, ushering in a new approach to heritage, now viewed in terms of processes, with a focus on the mechanisms by which heritage is produced, the issues at stake, the actors involved, and the various scales in play. This double issue continues to work in the same vein.

Mention may here be made of works that reinterpret the Ottoman heritage against the current backdrop of globalization (Bartu 1999, 2001; Öncü 2007, 2010), and those on the dynamics of heritagization in Istanbul (Göktürk, Soysal, \& Tureli 2010; Pérouse 2003; Dorso 2003, 2006; Girard 2010; Boucly 2013). Nation-building has been examined in the light of reinterpretations of the past and of local geography (Öktem 2003), of popular culture (Öztürkmen 1994, 1998, 2002), and more recently of phenomena being listed as intangible cultural heritage (Aykan, 2012a, 2012b, 2013). Other researchers have examined cultural policies (Karaca 2009), as well as "alternative" (Scalbert-Yücel 2009) and popular (Fliche 2007) heritage constructs and plural collective memories (Anastassiadou and Dumont 2003 inter alia). Finally, research has been carried out into the sudden increase in collective memory initiatives in Turkey (see for example Özyürek 2007 and the various publications by Leyla Neyzi). ${ }^{3}$

4 As things stand, greater interest tends to be paid to the objects than to the processes by which heritage is produced, and this despite the noteworthy works just mentioned. This is perhaps revelatory of conflicting logics in the heritagization process, or of a supposedly "Turkey-specific" heritage timeframe. Jean-François Pérouse has pointed out that the term "heritage" has no equivalent in Turkish, and that variations in vocabulary can to a certain extent be mapped onto political fluctuations (Pérouse 2011). Given this, the recent emergence within political discourse of the expression for cultural heritage (kültürel miras or kültür mirasl) and its increasingly widespread use (Pérouse 2004), ${ }^{4}$ together with the development of heritage as a category of public policy (Girard and Scalbert, 2015), are perhaps indicative of a revival/renewal or perhaps rather a proliferation of heritagization and its alignment with global dynamics. This shift also need to be viewed in the light of changes taking place within history studies, the renewal of historiography, ${ }^{5}$ and the recent first steps made towards exploring the painful and vivid collective memories of ethnic and political minorities. ${ }^{6}$

5 The relation between heritage and nation-building would appear to be of particular significance given the current political context in Turkey, and it strikes us as meriting closer study. Cultural policy has long been part of the project of nation-building. It still is today, as Jean-François Polo and Füsun Üstel point out, even though economic liberalization means it is now attributed new functions (Polo and Üstel, 2014). ${ }^{7}$ Equally, ideas about national culture change. ${ }^{8}$ In the early days of the Republic the objective was to "build up a national culture rooted in the land of Anatolia" (Fliche 2003: 566; see too the article by de Tapia in this issue). ${ }^{9}$ This involved the folklorization of regional specificities and the obliteration of non-Turkish-Muslim identities (Scalbert-Yücel 2005; Sauner 1995), as well as downplaying and on occasions burying the Ottoman past. 10

6 The national narrative was partially reworked in the light of the "Turkish-Islamic synthesis", the beginnings of which date back to the 1950s (Bora 1999). Developed by nationalists and clerics, "this ideology, which was built up during the 1970s, tended to represent the Turks as the champions of Islam, to a certain extent bringing about a nationalization of Islam and an Islamization of Turkish history" (Pérouse 2004: 211). It 
then took hold in the 1980s (in the wake of the military coup) and spread, coming to the fore in the 1980s and 1990s (Scalbert-Yücel 2005: 227). This "hitherto discreet conservative ideology could now be openly expressed, though without calling the values of Kemalism into question" (Copeaux 1999: 328). Its institutionalization was instrumental in the rehabilitation of the Ottoman past (Copeaux 1999).

Nowadays, the neo-Ottomanism promoted by the AKP [Adalet ve Kalkınma Partisi, the Justice and Development Party] is playing its part in the rewriting of the national story, with an insistence on the greatness of the Ottoman past. ${ }^{11}$ Writing about neoOttomanism, Nora şeni has commented on how this "word is used to describe the aspiration of actions which endeavour to draw on the values, styles, and policies (especially foreign policies) deemed to be Ottoman" (şeni 2010: 41). Seçil Yılmaz, for her part, observes that it promotes a multicultural model in reference to a golden age of the Ottoman Empire, embodying Muslim tolerance (Yılmaz 2005). Since the party came to power in 2002, AKP identity-driven action has been rooted in the value attached to Muslim and Turkish-Ottoman identity, or, depending upon the context, to multiculturalism. It should nevertheless be pointed out summoning up the Ottoman legacy in this manner is not the preserve of the AKP, and would instead seem to be taking place within a timeframe dating back to before the party came to in power..$^{12}$ In particular Ayfer Bartu (2001) points out that the centre-right government back in the 1980s was seeking to promote a watered-down vision of the Ottoman Empire in order to help develop tourism (see too Eldem 2010).

8 In the light of these re-writings and concomitant changes to the Kemalist model of the founding of the Turkish nation, it is well worth examining heritage production via the optic provided by nation-building-not least because the 2011 AKP general election campaign was based on the theme of the "mosaic"13 (Pérouse 2011), because traces of neo-Ottomanism may be seen at work in many different places, and because of the "regime of tolerance (surveillance) with regard to alternative heritage productions by Kurdish municipalities" (Pérouse 2011).

9 The current context of heritage production and the emergence of Turkey on the international stage brings out a seemingly paradoxical fact about the role played by exogenous actors in this process. They are active both via their involvement in international institutions, and in distinguishing a specifically national identity. Heritage invention is also associated with tourism, viewed as a means of local development.

10 Jean-François Pérouse's observation suggests we should view heritage initiatives in terms of territory, and look at the ways in which national ideology can fail to match local action. It is hence important to work on several different scales if we are to apprehend the processes of heritage production and the underlying issues at stake.

11 Finally, study of alternative heritage productions carried out by Kurdish municipalities reveals how heritage interventions can compete and become enmeshed with each other, leading to the adoption of strikingly similar approaches, whilst also showing that heritagization can fulfil varying purposes, thereby revealing the existence of multiple processes of identity construction (Girard \& Scalbert-Yücel 2015). And so if we are to study the dynamics at work within heritagization, we need to analyze the various heritage actors present, the specific historicity of each of the numerous heritage actions, and the differing conceptions of what heritage is-something which the twelve articles here all seek to do. 


\section{A multi-scale approach to observing heritage production}

The articles in this issue illustrate the place heritage studies has acquired in numerous disciplines, having been written by anthropologists, historians, an architectural historian, a sociologist, a researcher in communication studies, and a political scientist. They examine various objects, including intangible heritage, architectural and religious heritage, commemorative practices, and so on. What they all have in common, however, is a methodological apparatus according pride of place to narratives narratives about heritage, and collective memory as narrative. The life stories of the bearers of collective memory are granted prominence via the accounts they provide of traumatic events and their evocations of genocide (such as in Törne's article), as are those of heritage bearers such as dengbêjjs ${ }^{14}$ (in Schäfers'). These narratives accumulate and are intercut with literary accounts, given the increasing number of memoirs and publications of all genres, as well as televised and film accounts. ${ }^{15}$ The papers published here are attentive to discourse and representations, whilst also examining action and practice. And so, on the one hand, analysis of the ways in which institutions are interconnected, of their partnerships, and the various ways in which they intervene (in the articles by Ter Minassia and by Marquart) is accompanied, on the other, by observation of heritage practice in action, notably in terms of how it is received and consumed (in the papers by Pénicaud, Carney, and de Tapia).

But far from being a matter of drawing up some ever-expanding inventory, understanding the processes of heritage production needs to be rooted in attentive examination of the interaction between different scales (Revel 1996). This approach is adopted in all the papers published here. Marcel Roncayolo has called for research that looks at different scales and the ways in which they are interconnected (Roncayolo 2011), and the contributors here bring different spatial and temporal scales into contact (as does the compilation of articles in this issue).

The temporal dimensions certainly throw light on the heritagization process and on how the Turkish State and Turkish society are connected to the global context. The chronological approach brings out the continuities and changes occurring within the world of heritage, as well as making it possible to obtain a clearer perspective on what is habitually seen as some kind of clean break between the Ottoman Empire and the Turkish Republic (a break which is also brought into question by certain other objects of study, see Gourisse 2015, and Polo \& Üstel, 2014). The authors, most especially Stéphane Yerasimos (in an article that originally appeared in the journal İstanbul in 2005, and here published in a translation into French by Jean-François Pérouse), reveal the legacies and affiliations between heritage institutions and different forms of discourse about heritage. Equally, Manoël Pénicaud, in his close examination of the process by which the House of the Virgin Mary in Ephesus was nationalized, shows how the State can be fairly pragmatic and flexible in the way it goes about promoting heritage. Many authors have shown how heritage is linked to conflict (including Poulot 2004, and Gravari-Barbas \& Veschambre 2003), and have examined what is at work in the emotions heritage arouses (Poulot 2006; Fabre 2013). The "Gezi Park uprising" (Pérouse 2014), in 2013, against a controversial development project, mentioned by the authors (Ter Minassian, Zencirci, and Martin), is thus illustrative of the way in which 
heritage, beneath its apparently "dead beauty" (de Certeau, Julia, \& Revel 1993), may crystallize, reflect, and act as the receptacle for a protest movement exceeding the sphere of heritage and take hold of society as a whole. ${ }^{16} \mathrm{Just}$ as it may be revelatory of the hitherto forgotten and mistreated Other.

The Gezi Park project partook in the AKP-promoted neo-Ottomanism forming the backdrop to the articles presented here, and sometimes their object of study. The chronological approach brings out what is at work in the Turkish-Islamic synthesis and in neo-Ottomanism (Carney; Zencirci), whilst the diachronic approach makes it possible to apprehend social imaginaries, especially those relating to conquest (via films and television series as studied by Josh Carney. ${ }^{17}$ This makes it possible to compare and contrast national and public memory narratives, especially with regard to the issue of minority groups, the Armenian genocide, and the 1923 population exchange between Greece and Turkey. Annika Törne places her study of heritage within the "postgenocide context", thereby revealing a timeframe based on traumatic events that differs from that in official national constructs. ${ }^{18}$

Using different timeframes and comparing historiography and public memory/ memories raises questions about how timeframes can vary from one actor to another, and how the timeframes of heritage action relate to those of political history. In his analysis of heritage discourse Stéphane Yerasimos brings out how protecting heritage, "identity construction initiatives", and the idea of the nation can merge into one another. He also shows how a "modern conception of protection"19 arose in the 1970s in tandem with Turkey's opening up to the world and to international exchange in general. Ipek Tureli's article incites us to establish a dialogue between Turkish temporality - the history of heritagization and the "Turkish/Ottoman house" - and "the temporality of the world", that of post-war reconstruction and the role played by the Council of Europe in integrated heritage conservation during the 1970s phase of European construction. The temporality of heritage objects is contrasted to that of society. Vivienne Marquart examines heritage protection and the temporality of towns, specifically the rapid, large-scale urban changes taking place in Istanbul. The temporality of "heritage shifts" (Rautenberg 2003) may also be assessed in the light of religious and traditional practices which are still alive today (Pénicaud; Schäfers), as well as individual or collective memories upsetting the great national narrative given the present-day trend for commemorations.

17 Another goal has been to attend different spatial scales and how they interconnect (including the international, European, national, local, supranational, and transnational levels), and to be alert to the link between the local and the international. Heritage production may provide a way of positioning oneself within the context of globalization, ${ }^{20}$ as well as acting as a response to the external pulls of "attraction and repulsion". This means that any study of heritage production mechanisms needs to take into account the dissonances in the way local powers in different territories interact with international bodies. To caricature the situation in a somewhat reductionist manner, action by UNESCO is seen as an intrusion into local affairs in Istanbul (Gargin 2006), whereas in the South East of the country international bodies play a central role in the Southeastern Anatolia Development Project and act as the "driving force" behind heritage policy (Girard \& Scalbert-Yücel 2015). ${ }^{21}$

That is why it is necessary to work on different scales and shift between the national and the international, the local and the national. One of the findings to have emerged 
from works about public action in Turkey is how multiple factors operating on different scales are interwoven at the local level (Aymes, Gourisse, Massicard 2015). To what extent do local means of heritage production and their end-goals coincide with those being promoted at the national scale? What dissonances may be detected between heritage narratives? The papers published here show just how important it is to look at the territorial dimension if we are to understand the processes at work. Bahar Aykan brings out the link that holds between heritage and national identity on the one hand, and supranational heritage construction on the other. Aykan, by looking at the emblematic case of the Nevruz ${ }^{22}$ being recognized by UNESCO as intangible cultural heritage at the request of Turkey, Iran, Azerbaijan, India, Kyrgyzstan, Uzbekistan, and Uzbekistan. Benjamin Weineck places a transnational space at the heart of his analysis in order to apprehend identity-based conflicts via traditional Alevi practices in Turkey and Germany. Various papers work on a different scale and examine "proximity effects", and in particular how the nearby presence of particularly heritagized sites can influence whether others sites tend to be promoted (Pénicaud) or effaced (de Tapia). Furthermore, the question of the traces left by the Armenian presence arises differently depending upon the place in question (Ter Minassian; Törne). And Annika Törne reminds us of how important it is to take into account a topography of memory, for memory is rooted in specific places (Halbwachs 1997). She shows that the construction of "remembrance sites" (Nora 1984) can on occasions seen tenuous. Furthermore, though the "return to the district" - to use Cilia Martin's expression - has been a topic of research for several years now, ${ }^{23}$ she shows how the current wave of people moving back to the former Rum district of Kurtuluş brings transnational actors and various context effects into play, notably in the wake of the Gezi Park events. Ipek Tureli, for her part, traces how the international emergence of the idea of open museums and the importance now attached to the urban fabric altered perceptions about the heritage interest of this neighbourhood.

In addition to these similarities in approach, several themes run through various of the papers presented here. Each theme addresses the link between heritage and nationbuilding, enquiring into the mechanisms, stakes, actors (particularly the role played by the State), and effects of heritage production.

\section{Shifting trends in heritage and nation-building in contemporary Turkey}

\section{Heritage and identity building - nostalgia, authenticity, and the invention of tradition.}

The papers presented here all look at the category of heritage together with various of its sub-categories, such as "Armenian heritage", the "Turkish/Ottoman house", and so on. They examine the way these categories are built up, their meaning, and the effects that they have. They all examine how relevant these categories are, sometimes preferring the notion of "legacy" (héritage in French) to that of heritage (patrimoine in French) as a category for public action, arguing that it better captures the "ultra-local and familiar" nature of traces (de Tapia) and memories when accounting for "past usages not quite included in the process of official heritagization" (Martin). Within the context provided by the current proliferation in heritage and public memory issues, 
ever greater demands relating to cultural diversity, and the increasing emergence of minority legacies within the heritage realm, a certain number of paradoxes may be detected relating to the essentialization and malleability of culture in the multiple recompositions it undergoes. The case studies present "inventions of tradition" (Hobsbawm \& Ranger 1983) that took place within the context of nation-building, but which are topical once again within the current context of globalization (Dimitrijevic 2004). Common mechanisms may thus be found between Turkish and Kurdish constructions of nationalism (Aykan; Schäfers) that also transpire in demands being made by minorities, as shown for instance by the case of the Kurtuluş district (Martin). It needs to be remembered that authenticity is a key part in heritage production (Heinich 2009). Studies of intangible heritage (Schäfers; Aykan; Weineck) show how this is reconstructed, and Turkified or Kurdified depending upon the context, before being reified on gaining recognition. The reconstruction of a typically Ottoman street (or the mediatization of a romanticized version of national history in films and television series (Carney)) is indicative of an idea of authenticity that is not necessarily a matter of purity, integrity, and how things once were ${ }^{24}$ As Carney observes, referring to a Turkish saying, imitations bring the original to life. Nevertheless, the conflictual nature of reconstructions can surface, meaning that the charge of inauthenticity is frequently made (Schäfers; Weineck).

21 Furthermore, "nostalgia is a major force in heritage" (Berliner 2013: 394). Nostalgia acts as the motor for both production and reception, and is endowed with a performative dimension since it operates in tandem with the appropriation of Ottoman heritage via narratives and imaginary constructs. ${ }^{25}$ Josh Carney and Ipek Tureli, referring to Svetlana Boym's analysis (2001), bring out the ambiguous nature of nostalgia, which can involve both restoration of the past and the adoption of a certain critical distance with regard to it. Finally, study of heritage as a category, of the ways in which it is staged, and of the usages to which the past is put show how forceful and effectual a category it is, as illustrated by the example of the increasing power of religious foundations [vakıf] qua "Ottoman heritage for civil society" (Zencirci).

\section{Nation-building and economic issues - heritage as a resource}

In the eyes of the governing AKP, heritage is a useful means of binding the national community together. Identity stakes and economic stakes intersect here given the dual context of tourist development and the liberalization of the economy which has been under way since the 1980s. Hence the hoped-for tourism dividends and the need "to forge a condensed image of oneself that can be proposed to visitors" (Sauner-Leroy 2000) are both factors influencing heritage invention. However, the link between tourism, nation-building, and heritage is anything but recent. Arzu Öztürkmen points out how domestic tourism, a theme of nationalist literature, is perceived as a way to develop national sentiment (Öztürkmen 1994: 169-170). On being invited to Istanbul in 1959, André Gutton, Chairman of the "Urbanism" Committee of the International Union of Architects (UIA), envisaged maintaining the historic fabric of Istanbul for tourism purposes (Yerasimos). Manoël Pénicaud, for his part, shows how ever since the 1950s the State has seen the heritage foundation of the House of the Virgin Mary in Ephesus as a lever for developing tourism and the economy. In the 1960s the expression "tourist heritage" was in use (Akoğlu 1968), and the two terms became even more closely intertwined over the course of the following decades with the development of 
international tourism. Laurent Mallet's study of the "strategic tourism development plan for Turkey" drawn up by the Ministry of Culture and Tourism (Mallet 2007) notes that all forms of tourism were considered. For several decades the number of tourists has been continually on the up, and in 2013 there were 35 million foreign visitors (Pénicaud), while domestic tourism also expanded. And various different forms of tourism are based on heritage elements, such as cultural or religious tourism or that associated with collective memories. Above and beyond its economic aspect, tourism, perceived as an asset for local public development initiatives, acts as a "mirror" for identity constructs (Cousin 2011). Heritage is thus taken as a tool to develop tourism. And, conversely, the fact that tourists visit a site can be instrumental in its heritagization, promoting it to the status of a site of remembrance, or else marginalizing it when a site is not on the tourist circuit or else deemed not to conform to the image of alterity the visitors expect to receive. Tourism would thus appear to act as the obverse to the building up of a national narrative and to the elaboration of identity strategies, perhaps resulting in a less strongly delineated picture. It is thus symptomatic that a large number of the papers in this issue look at tourism, either in passing or else as one of their central focuses.

The economic dimension of heritage does not relate solely to tourism. Josh Carney shows how the culture industry has started making films and television series about the Ottoman Empire. Commodification is also visible when place names, in this instance the name of a district, are taken up as a brand name playing on nostalgia or urban conflict, as is the case with "Tatavla" (Martin).

\section{Heritagization instruments, approaches, and objects - tools to safeguard, disseminate, contest, and exert control}

One of the aims of this thematic issue of the EJTS is to enquire into the tools used in heritagization, and especially how they have been imported, how they circulate, and how they have been reformulated, not least because Turkey has ratified all the great international conventions on heritage. By examining both official and "alternative" heritages, all the studies presented here address this question in their own manner. There are four noteworthy points here. The first, which has already been made in studies of the Convention for the Safeguarding of the Intangible Cultural Heritage, relates to how this tool is used to help build the nation-state (Aykan). The examples provided by the listing of the "Nevruz" and the "Semah, Alevi-Bektaşi ritual" show how, though Turkey is no longer in the negationist phase which prevailed during the early days of the Republic, this instrument can still be used to exert control, impose norms, recuperate, and depoliticize the cultural traditions of minority groups (the Kurds and Alevis) via a process of State-led museumification. But instruments may also be used in the struggle to win recognition from the other within a space no longer thought of in national but in transnational terms, as shown by the Alevis in Germany and their demands for their semah practices to be recognized as heritage (Weineck).

Secondly, the proliferation of heritage may be seen in the many tools used to convey and transmit social imaginaries. A clear example of this is afforded by the popularization and mediatization of the Ottoman past by television series and films, and even of the way the Ottoman Christian past has been neglected, to say the least, by official circuits (de Tapia). ${ }^{26}$ Further examples are provided by magazines, exhibitions, 
and collective memory writings. Heritage thus spills out from its erudite and professional sphere and becomes more socially widespread.

Thirdly, changes may be observed in ways of treating heritage, with the shift from protection focusing solely on monuments to the new approach promulgated by the 1973 law which, in tandem with ideas in Europe, promotes the preservation of monuments within their context (Yerasimos; Tureli). But divergences may be detected between local conceptions of heritage at Istanbul and the ideas of UNESCO (Marquart). Several authors point out that interventions can in fact resemble a form of destruction (Ter Minassian; de Tapia), leading to the as yet unexplored question of the way the experts involved think of heritage and the concrete means of action taking place. These acts of destruction can be part of a larger process of urban regeneration or else related to awkward objects associated with a past that is denied (Törne). Taline Ter Minassian points out that, in addition to restoration and demolition, another important means of action is the drawing up of inventories. This can act as a preliminary stage in heritage recognition, being a means of selection in which phenomena are made visible or else effaced. Basing her analysis on the example of Armenian artefacts, she shows how the means of selection retained result from a series of laws and discussions between the State, foundations, and civil society actors, taking place within the context of "efforts to democratize Turkey".

Lastly, mention needs to be made of the whole battery of instruments associated with heritage action, including the ratification of conventions, the passing of laws (in 1874, 1906, 1973, and 1983, as well as recent laws about urban transformation and foundations), the founding of institutions, agencies, and departments, and the setting up of partnerships, together with the role played by foundations and associations. This acts as a corrective to the idea that heritage is a comparatively recent phenomenon in Turkey and one that fails to elicit much interest. It also shows that public action is being reshaped, something which has for that matter already been noticed in relation to other sectors (Aymes, Gourisse, Massicard 2015).

\section{Nation-building and competing ways of thinking about heritage - the makers, bearers, and consumers of heritage}

In his introduction to the "worlds of heritage", Dominique Poulot points out that numerous actors are involved in heritage production (Poulot 2006), including public/ private actors, civil society organizations, and State institutions, not to mention groups and individuals. Furthermore, Benoît Fliche in his study of migrations, comments how we need to shift our focus away from heritage when studying Turkey, and look instead at "grass-roots heritagization" acting outside any official framework (Fliche 2007; see too Rautenberg 1998, 2003; David \& Müller-Celka 2010). Equally, observations of public action in the Southeastern Anatolian region (Girard \& Scalbert-Yücel 2015) led to an approach being privileged in which "there is no difference between actors as a matter of nature. ${ }^{27}$ All the differences in level, size, and scope are the result of a battle or a negotiation" (Callon \& Latour 2006: 12).

The papers discuss numerous actors - experts, national institutions, local institutions, enthusiasts, laypeople, public actors, and private actors - and show how they have different ways of thinking about heritage. They also bring out the ways in which these 
ideas can influence each other, intersect, and show extensive agreement on certain points, or else on the contrary disagree.

If we look at the makers of heritage, various papers raise the question of the role played by the State in heritage production, bearing in mind that the traditional model of a strong State is being revisited and nuanced, with the reality of the situation being seen as more complex (Gourisse 2015).

Public heritage action is conducted via a plethora of institutions (both at the municipal level and at the State level, starting with the Ministry of Culture and Tourism) and many different partnerships. Several of the authors mention the role mayors play in getting hitherto forgotten heritage recognized, such as Armenian heritage, or Christian Ottoman heritage in Cappadocia (Ter Minassian; de Tapia). The sort of public action and the ways in which it is being reformulated would appear to pave the way to a withdrawal by the State. Nevertheless, once these situations have been put into due perspective, what emerges is the idea of "centralized fragmentation" (Marquart) of a "pragmatic rationale" adopted by the State (Pénicaud) within the context of debates about democratization, and demands for cultural diversity and more diverse tourism amenities.

Furthermore, in addition to the international bodies mentioned above, various foreignbased organizations are also involved in heritagization, such as the Association Terre et Culture which is based France (Ter Minassian), or the members of the Alevi community in Germany [Almanya Alevi Birlikleri Federasyonu]. That is why recognition of the heritage of minority groups in Turkey - its recognition at local level and its being regarded as part of the nation's heritage - is also built up within transnational spaces.

Another striking aspect is the role played by individuals in the production of heritage, including heritage entrepreneurs, politicians, intellectuals, and men of science. They all play an active role in promoting national heritage, as was the case of Çelik Gülersoy who was head of the Touring Club of Turkey (Tureli). They also take part in promoting cultural diversity, as for example Osman Kavala did as head of the Anadolu Kültür foundation (Ter Minassian). Individuals thus act as relays for a collective heritage that has or is in the process of being built up. Others play a role as inventors or as catalysts, helping to establish collective dynamics, as illustrated by the efforts to make the district of Kurtuluş a place of collective memory (Martin).

It would thus appear that civil society plays a major part in heritage production. But despite this Gizem Zencirci, in looking at how the AKP uses the heritage of Ottoman civil society, shows that heritage can be a tool for actually neutralizing that same civil society. And so when enquiring into how the State's perception of heritage relates to that of society; we need to take the transnational dimension into account together with the numerous situations and plural nature of society.

In addition to this Gizem Zencirci also suggests we shift our focus away from the makers of heritage towards its bearers. She looks at the processes used to manufacture and promote the Ottoman heritage whilst showing how civil society actors are not necessarily all working towards the same goals. Looking at the bearers of heritage brings to light the negotiations and accommodations that take place. These reveal various limitations, for instance female dengbêjs do not identify with Kurdish nationalist classifications of Kurdish culture, reckoning that lacking in authenticity (Schäfers). And in the event where the heritagization process is based on the accumulation of individual memories and on operations to transpose and translate 
them, this also raises the issue - given the question of knowing how "the set of images that I have assimilated and built up in my own personal imaginary is subsequently shared and socialized" (Rautenberg 2007-2008: 46) - of the relationship that holds between the individual and the group.

This leads to the question of publics. Observations of how heritage is received and consumed show that it may act as an element of cohesion, being disseminated at different levels of society. The widespread enthusiasm for heritage and the expansion of domestic tourism amongst the upper and middle classes lend support to analyses of heritage in terms of a society of leisure and culture. It nevertheless needs to be borne in mind that there are pronounced social economic disparities in Turkey, and that individuals and social groups have highly stratified relationships to heritage. Having said that, the enthusiasm for the Ottoman past is exemplary, as is the fact that it is beamed into the living rooms of Turkish families via television series (Carney). And irrespective of whether this past is perceived with emotion or with critical distance, it clearly becomes part of daily life.

The other significant point about publics is the "return" of the descendants of people who took part in the 1923 population exchange between Greece and Turkey. A form of tourism has started to build up over the past few years based on this collective memory (de Tapia; Pénicaud). Reference also needs to be made to the commemorative practices of the descendants of those who survived the Armenian genocide at Tunceli (Törne).

\section{Heritage constructions and the dynamics driving their (in)visibility}

Heritage is a matter of selection and choice, of which the counterpart is effacement and oblivion. Grégory Busquet, Claire Lévy-Vroelant, \& Caroline Rozenholc (2014) have suggested studying heritage issues in terms of the relationship between the dominant and dominated. Within this process certain actors are "rendered invisible" (AlSayyad, in reference to Broudehoux 2001: 24). And heritage production in Turkey shows that "legitimizing identities" (Castells 1999) - i.e. those imposed by the dominant actors within society - undoubtedly still retain their effectiveness. At the same time other identity constructs may be seen to be emerging, whether positioned as alternatives to the national project or else seeking to exert an influence over it. The mobilization of minority groups could suggest that the national narrative is being eroded. Still, the State would appear to act as an incubator. Firstly, because the relationship to heritage is not fixed (either spatially or temporally). An illustration of this is provided by the attitudes towards Byzantine heritage, which can range from rejection to promotion (Pérouse 2003; Dorso 2003; and in this issue Pénicaud; de Tapia). Equally, tensions relating to the "Kemalist/Republican heritage" and how its various objects are treated ${ }^{28}$ are indicative of contests over defining what counts as official heritage, this having been continually reinvented since the early days of the Republic. Secondly, the regime of "surveillance - tolerance" identified by Jean-François Pérouse with regard to Kurdish municipalities and which might also be extended to certain operations relating to Armenian heritage would appear to be part of a similar phenomenon. Certain elements must still be kept invisible because they apparently disrupt the national construct to too great an extent. ${ }^{29}$ In addition to this the authors point out how much the official historiography and the national narrative continue to exert considerable power over 
the Armenian and Rum heritage, and the collective memory of the genocide and population exchange.

Hence a heterogeneous dynamic of heritagization may be seen to be at work. Acts of commemoration occur alongside the obliteration of traces via the destruction of buildings, or else interact with the mechanisms of inclusion/exclusion of Kurdish (Aykan) and Alevi (Weineck) ${ }^{30}$ cultural traces and the attendant feeling of dispossession. These acts are of varying degrees of "privacy", and, whilst marginal, can involve official actors and even be instigated by them (de Tapia; Törne; Ter Minassian).

The multi-scale approach shows that the processes by which traces are rendered (in)visible do not operate solely within the framework of official versus alternative undertakings. It also picks up on the power relations at work within society and on the effects of distancing. The "heritage shift" (Rautenberg 2003) may also be detected in the decontextualisation of heritage and of the phenomena collective memories are rooted in. Ipek Tureli points out that heritagizers do not live in "Ottoman/Turkish houses" but observe from afar, whilst Cilia Martin notes that the promotion of Kurtuluş as a place of memory has taken place independently of the population living there today and of the district's socio-economic situation. Instances may also be found of heritage being used for other motives, such as the case of female dengbêjs and the political dimension at work behind the choice of songs within the context of Kurdish nationalism. Finally, Annika Törne emphasizes how certain local actors, in their wish to have the 1938 Armenian and Alevi massacre at Dersim (Tunceli) recognized as acts of genocide, pass over the 1915 genocide in silence, thus conforming to the hegemonic discourse of denial.

41 Tactics, strategies, and affirmations about what may and may not be said are part of a larger setting in which memory and heritage issues represent a national challenge for present-day Turkey, and one that extends beyond the borders of the country given its place within transnational spaces.

\section{Organization of this double issue}

This thematic issue is composed of two volumes. Whilst each article is attentive to the political and ideological context within which heritage production takes place, especially since the AKP's arrival in power, they have been organized on the basis of their angle of attack. We have decided to distinguish between papers studying official heritage as promoted and sanctioned by the State or else working with its themes, from those starting from "alternative heritage", identity demands, multiple collective memories, and the issue of minorities. It is this aspect which we have endeavoured to bring out in the brief exposé which follows, and which does no more than provide a particular take on the articles in question.

The first volume - Producing an Official Heritage in a Time of "Neo-Ottomanism": Critical Approaches - is based on three different approaches.

The first approach is based on focusing on the production of categories and the setting up of instruments. The article by Stéphane Yerasimos (translated here by Jean-François Pérouse) sets out a useful framework within which to discuss heritage protection in Turkey from the Tanzimat to 2005 and, beyond this, the links between heritage, identity construction, and national values. Ipek Tureli deciphers the 1970s 
heritagization of the "Turkish/Ottoman house", a symbolic object of nationalism that had been codified and studied since the first decades of the $20^{\text {th }}$ century. His article conducts careful examination of the actors, associations, and networks involved. She shows how it underwent certain modifications, arguing that this process was generated by the intense urbanization taking place locally, by international trends and changes in ways of doing things, and by legislation, as well as stemming from the enthusiasm of an elite that cast itself in the role of heritage saviour. Conservation practices, often accused of being inadequate, may in fact be part of a strategy for urban management within a context of pronounced change. This is the hypothesis put forward by Vivienne Marquart via her analysis of the heritage management system in Istanbul. By unpicking the complex system of institutions at State and municipal level, she explores the gaps that opened up between UNESCO's approach to heritage and the means actually deployed for urban regeneration, as well as the divergent interests and objections that arose to locally.

The second approach relates to Ottoman heritage as narratives and assets. Josh Carney's observations concentrate on recent audiovisual fictions set in the Ottoman Empire, and the success or failure they have encountered. He resituates these works in relation to neo-Ottomanism, exploring how this concept has evolved over time. He shows that they deploy different approaches to nostalgia - restorative nostalgia, which is akin to reconstitution, and reflective nostalgia (in reference to Boym 2001) involving different publics as a result. The use made of the Ottoman narrative goes further than this, however, and the ambition would appear to be to bring about a change in the structures of civil society. Gizem Zencirci shows that the AKP's reconstruction of the Ottoman heritage, and in particular the role accorded to vakifs, has been a factor in the shifting relationship between the State and civil society and the emergence of a "collaborative model". This ties in with a neoliberal perspective and tends to exclude those who do not conform to it and, above and beyond this, actively reshapes the relationship between the State and society.

The third relates to the nationalization and heritagization of objects which are marginal to the national heritage. Bahar Aykan examines the classification of phenomena on the UNESCO list of intangible heritage and how this has been used by the State to neutralize, appropriate, and nationalize the heritage in question. In order to do so she looks conjointly at the classification of Nevruz as part of the intangible heritage of Turkey and the significance this festival has for Kurds, together with the PKK's (Kurdistan Workers' Party) adoption of this tradition during the mid-1980s. Manoël Pénicaud, for his part, goes back over the history of the House of the Virgin Mary in Ephesus "from its foundation to its heritagization as an 'international' sanctuary", demonstrating how exceptional the heritagization of this prime tourist site has been given how Christian heritage tends to be treated in Turkey. This "nationalized" heritage site is a place where pilgrims and tourists, Christians and Muslims all come together.

The second volume - "Alternative heritages", the tribulations of recognition looks at heritage production from the point of view of the "dominated" and the marginal status it has in comparison to official heritage.

The first theme examines the emergence and neglect of heritage objects together with hindrances and obstacles within the process of heritage production. Taline Ter Minassian and Annika Törne track the processes by which the Armenian past and 
Armenian heritage are rendered (in)visible. Taline Ter Minassian looks at "heritage inversion" by analyzing the operations to promote Armenian heritage - by restoring it or drawing up inventories - together with the "constellation" of actors involved. Annika Törne examines the Tunceli/Dersim case and the impact of denial, bringing out the mismatches in the collective memory narratives of the Armenians, and highlighting the visible physical impediments to the actions of local actors. Aude Aylin de Tapia delves beneath the surface of things to discover that which is hidden and excluded from tourist circuits. She looks at the traces of a past - that of Ottoman Christian Cappadocia - which does not correspond to the dominant national ideology nor the images that are produced of heritage in this place - a past which in fact challenges the "great historical narratives" since it recalls the "dramatic" event of the 1923 population exchange, and would thus appear to have been (voluntarily) forgotten. She then goes on to examine the processes by which it has been made increasingly visible over recent years.

The next three articles adopt different levels of reading to examine nationalism and transnationalism in relation to identity demands and the heritagization of plural cultures. Cilia Martin analyses how "the district of Kurtuluş in Istanbul is presented as a place of collective memory", showing that this "return to the original district" has arisen at least in part due to the involvement of Greek "memory entrepreneurs" (Pollak 1993, quoted by Martin) - although the phenomenon exceeds this initial circle, and due attention to how the Rum past of this district has been rewritten brings out the exogenous nature of the actors involved. Benjamin Weineck enquires into the alternative project of Alevis in Germany to get the semah recognized as heritage (bearing in mind that the ritual is already recognized by UNESCO as part of Turkey's intangible cultural heritage), examining the usages to which the past is put in this transnational space and the underlying issue of recognition which is at stake. Lastly, Marlene Schäfers examines a different form of nationalism by observing the production of the dengbêj as a figure of Kurdish cultural heritage in modern-day Turkey. By examining the example of female dengbêjs she unravels how complex this process is, where this complexity is bound up with the need to be acceptable within the context of domination. This is an instance of the essentialization of culture that can take place to the detriment of the signifying elements of the heritage bearers. Hence the mechanisms of heritagization used for nationalism - be it Turkish or, as in this instance, Kurdish - may be seen to draw on fundamentally similar tools.

\section{BIBLIOGRAPHY}

Akoğlu, Tunay (1968) "Évolution, importance et avenir du tourisme en Turquie", Les Cahiers du tourisme, série B, 6 .

AlSayyad, Nezar (eds.) (2001) Consuming Tradition, Manufacturing Heritage. Global Norms and Urban Forms in the Age of Tourism. Londres - New-York, Routledge Taylor and Francis group. 
Anastassiadou, Méropi; Dumont, Paul (2003) “Une mémoire pour la ville : la communauté grecque d'Istanbul en 2003”, Istanbul, Les dossiers de l'IFEA : La Turquie aujourd'hui, n 16 . URL: http:// books.openedition.org/ifeagd/226

Aykan, Bahar (2013) "How Participatory is Participatory Heritage Management? The Politics of Safeguarding the Alevi Semah Ritual as Intangible Heritage", International Journal of Cultural Property, 20, pp. 381-405 URI: http://dx.doi.org/10.1017/S0940739113000180

Aykan, Bahar (2012) “UNESCO ve Kültürel Mirasın Milliyeti” in Yelsali Parmaksız P. M. (ed.) Neye Yarar Hatıralar? Bellek ve Siyaset Çalışmaları, Ankara, Phoenix, pp. 303-337.

Aykan, Bahar (2012) Intangible heritage's uncertain political outcomes: nationalism and the remaking of marginalized cultural pratices in Turkey, Ph. D, University of New York.

Aymes, Marc; Gourisse, Benjamin; Massicard, Élise (2015) Order and Compromise: Government Practices in Turkey from the Late Ottoman Empire to the Early 21st Century, Leiden, Brill.

Bahrani, Zainab; Çelik, Zeynep; Eldem, Edhem (2011) Scramble for the Past: A Story of Archaeology in the Ottoman Empire, 1753-1914, Istanbul, SALT.

Bartu, Ayfer (2001) "Rethinking Heritage Politics in a global context: a view from Istanbul", in AlSayyad, Nezar (ed.), Hybrid Urbanism: On the Identity Discourse and the Built Environment, London, Praeger, pp. 131-155.

Bartu, Ayfer (1999) "Who Owns the Old Quarters? Rewriting Histories in a Global Era", in Keyder, Çağlar (ed.), Istanbul. Between the Global and the Local. Lanham, Md, Rowman and Littlefield Publishers, pp. 31-44.

Berliner, David (2013) “Nostalgie et patrimoine. Une esquisse de typologie”, in Fabre, Daniel (ed.), Émotions patrimoniales, Paris, Éditions de la Maison des sciences de l'homme ethnologie de la France, pp. 393-409.

Biner, Zerrin Özlem (2007) "Retrieving the Dignity of a Cosmopolitan City. Contested Perspectives on Culture, Rights and Ethnicity in Mardin", New Perspectives on Turkey, 37, pp. 31-59. URL: http://www.newperspectivesonturkey.net/Journal/Issue/22

Boucly, Julien (2013), “Coopération et conflictualité sur le site du patrimoine mondial d'Istanbul”, essay submitted to the Institut d'Études Politiques de Lille. URL: http://oui.hypotheses.org/201

Bora, Tanil (1999) “Istanbul of the Conqueror : The ‘Alternative Global City' Dreams of Political Islam”, in Keyder, Çağlar (ed.) Istanbul. Between the Global and the Local, Lanham, Rowman and Littlefield Publishers, pp. 47-56.

Boym, Svetlana (2001) The Future of Nostalgia, New York, Basic Books.

Busquet, Grégory; Lévy-Vroelant, Claire; Rozenholc, Caroline (2014), "Introduction”, Articulo Journal of Urban Research, $n^{\circ} 5$, special issue "Mémoires dominantes, mémoires dominées. La fabrique des patrimoines urbains en question". URI: http://dx.doi.org/10.4000/articulo.2490

Burdy, Jean-Paul (2011) “La démolition du monument de l'Humanité à Kars et les relations turcoarméniennes : un signal négatif”, Observatoire de la vie politique turque, http://

ovipot.hypotheses.org/5614

Callon, Michel; Latour Bruno (2006) “Le grand Léviathan s'apprivoise-t-il ?”, in Callon, Michel; Latour, Bruno; Akrich, Madeleine, Sociologie de la traduction. Textes fondateurs, Paris, Presses de l'École des Mines de Paris, pp. 11-32. URL: http://economix.fr/pdf/seminaires/conventions/ 2007-01-23_LATOUR-b.pdf

Castells, Manuel (1999) Le Pouvoir de l'identité, Paris, Fayard. 
Certeau, Michel de; Julia, Dominique; Revel, Jacques (1993) “La beauté du mort”, in Certeau, Michel, La culturel au pluriel, Paris, Seuil, pp. 45-72.

Chyet, Michael (2003) Kurdish English Dictionary, New Haven-Londres, Yale University Press. Copeaux, Étienne (1999) "La nation turque est musulmane. Histoire, Islam, Nationalisme en Turquie”, Les Annales de l'Autre Islam, n 6, pp. 327-342.

Copeaux, Étienne (1997) Espaces et temps de la nation turque, Analyse d'une historiographie nationaliste 1931-1993, Paris, CNRS Éditions, 1997.

Cousin, Saskia (2011) Les Miroirs du tourisme. Ethnographie de la Touraine du Sud, Paris, Descartes et cie.

David, Jean-Claude; Müller-Celka, Sylvie (eds) (2010), Patrimoines culturels en Méditerranée orientale : recherche scientifique et enjeux identitaires, $4^{\text {th }}$ panel (25 November 2010): Patrimoine institutionnel et patrimoine populaire. L'accession au statut patrimonial en Méditerranée orientale, Lyon, Rencontres scientifiques en ligne de la Maison de l'Orient et de la Méditerranée. URL: http:// www.mom.fr/4eme-atelier.html.

Dimitrijevic, Dejan (ed.) (2004) Fabrication des traditions, invention de modernité, Paris, Éditions de la Maison des sciences de l'homme.

Dorso, Franck (2006) "La muraille ignorée ou le paradoxe de l'alliance tourisme-patrimoine", Téoros, vol. 25, no ², pp. 40-46. URL: http://teoros.revues.org/1421

Dorso, Franck (2003) “Un espace indécis au cœur d'Istanbul. La muraille de Théodose II en 2001", Les dossiers de l'IFEA : Patrimoines au présent, $n^{\circ}$ 1. URL: http://books.openedition.org/ifeagd/202

Eldem, Edhem (2010) Un Orient de consommation, Istanbul, Musée de la Banque ottomane.

Fabre, Daniel (ed.) (2013) Émotions patrimoniales, Paris, Éditions de la Maison des sciences de l'homme.

Fliche, Benoît (2007), Odyssées turques : les migrations d'un village anatolien, Paris, CNRS.

Fliche, Benoît (2003) "Les vacances de Kayalar. Histoire migratoire, usages et représentations d'un village anatolien en milieux urbains (Turquie, France)", doctoral dissertation, Aix-enProvence, Université d'Aix-Marseille 1.

Gargin, Hamdi (2006) “Istanbul - Capitale Culturelle Européenne 2010”, Lettre de l'Observatoire urbain d'Istanbul, n² 24, pp. 29-32.

Girard, Muriel (2010) "Recompositions du monde artisanal et mutations urbaines au regard des mises en patrimoine et en tourisme au Maghreb et au Moyen-Orient (Fès, Istanbul, Alep)", doctoral dissertation, Tours, Université de Tours.

Girard, Muriel; Scalbert-Yücel, Clémence (2015) “Heritage as a Category of Public Policy in the Southeastern Anatolia Region”, in Aymes, Marc; Gourisse, Benjamin; Massicard, Élise (eds), Order and Compromise: Government Practices in Turkey from the Late Ottoman Empire to the Early 21st Century, Leiden, Brill, pp. 192-218.

Göktürk, Deniz; Soysal, Levent; Tureli, Ipek (2010) Orienting Istanbul. Cultural Capital of Europe?, London and New York, Routledge.

Gourisse, Benjamin (2015) "Order and Compromise: The Concrete Realities of Public Action in Turkey and the Ottoman Empire”, in Aymes, Marc; Gourisse, Benjamin; Massicard, Élise (eds), Order and Compromise: Government Practices in Turkey from the Late Ottoman Empire to the Early 21st Century, Leiden, Brill, pp. 1-24. 
Gravari-Barbas, Maria; Veschambre, Vincent (2003), "Patrimoine : derrière l'idée de consensus, les enjeux d'appropriation de l'espace et des conflits", in Melé, Patrice; Larrue, Corinne; Rosemberg, Muriel (eds) Conflits et territoires, Tours, Presses universitaires François Rabelais, pp. 67-82. URL: http://books.openedition.org/pufr/1831

Gümüş, Korhan (2009) “Deux projets de la République pour Istanbul”, La Pensée de midi, n²9, p. 81-85. URL: http://www.cairn.info/revue-la-pensee-de-midi-2009-3.htm

Halbwachs, Maurice (1997) [1950] La mémoire collective, Paris, Albin Michel.

Hartog, François (2002) Régimes d'historicité, Présentisme et expériences du temps, Paris, Le Seuil.

Heinich, Nathalie (2009) La fabrique du patrimoine. "De la cathédrale à la petite cuillère", Paris, Maison des Sciences de l'Homme.

Hobsbawm, Eric; Ranger, Terence (eds) (1983) The Invention of Tradition, New York, Cambridge University Press.

Karaca, Banu (2009) "Governance of or through culture? Cultural policy and the politics of culture in Europe", in Focaal - Journal of Global and Historical Anthropology, vol. 2009, No.55, 27-40p. URI: http://dx.doi.org/10.3167/fcl.2009.550103

Mallet, Laurent (2007) "Le tourisme en Turquie : de la manne financière aux changements de mentalités”, Hérodote, n 127, pp. 89-102. URI: http://dx.doi.org/10.3917/her.127.0089

Marcou, Jean (2012), “Le néo-ottomanisme, clef de lecture de la Turquie contemporaine ?", Les Clés du Moyent-Orient, http://www.lesclesdumoyenorient.com/Le-neo-ottomanisme-clef-delecture.html.

Martin, Cilia (2013) “Études sur le quartier dans l'Empire ottoman et en Turquie”, Dipnot URL: http://dipnot.hypotheses.org/593.

Monceau, Nicolas (2006) "Contribution à une sociologie politique des élites réformatrices Le cas de la Fondation d'Histoire de Turquie Trajectoires, mobilisation, attitudes 1980-2005", doctoral dissertation, Grenoble, Institut d'Études Politiques de Grenoble (Université Pierre-Mendès France - Grenoble II)

Navaro-Yashin, Yael (2013) "Editorial-Breaking Memory, Spoiling Memorization : The Taksim Protest in Istanbul”, Fieldsights-Hot Spots, Cultural Anthropology Online, October 31, http:// www.culanth.org/fieldsights/411-editorial-breaking-memory-spoiling-memorization-thetaksim-protest-in-Istanbul

Neyzi, Leyla (2008) review of Özyürek, Esra (ed.), Politics of Public Memory in Turkey, H-Memory, HNet Reviews, October 2008, http://www.h-net.org/reviews/showpdf.php?id=15709

Neyzi, Leyla (2010) “Oral History and Memory Studies in Turkey”, in Kerslake, Celia; Öktem, Kerem; Robins, Philip (eds.) Turkey's Engagement with Modernity: Conflict and Change in the Twentieth Century, Palgrave Macmillan, pp. 443-459. URL: https://research.sabanciuniv.edu/12634/1/neyzipalgrave22.1.09.doc

Nora, Pierre (ed.) (1984) Les Lieux de mémoire, Paris, Gallimard, vol. 1: La République.

Öktem, Kerem (2009) “Un cosmopolitisme sans fierté", La Pensée de midi, nº 29, pp. 18-24. URL: http://www.cairn.info/revue-la-pensee-de-midi-2009-3-page-18.htm

Öktem, Kerem (2003) “Creating the Turk's Homeland: Modernization, Nationalism and Geography in Southeast Turkey in the late19th and 20th Centuries", Paper for the Socrates Kokkalis Graduate 
Workshop 2003, The City: Urban Culture, Architecture and Society. URL: http://file.setav.org/Files/Pdf/ creating-the-turk\%E2\%80\%99s-homeland-modernization-nationalism-kerem-oktem-2003.pdf Onar, Nora Fisher (2009) "Echoes of a Universalism Lost: Rival Representations of the Ottomans in Today's Turkey”, Middle Eastern Studies, 45 (2), pp. 229-241 URI: http://dx.doi.org/ $10.1080 / 00263200802697290$

Öncü, Ayșe (2011), “Representing and Consuming the 'East' in Cultural Market”, New Perspectives on Turkey, special issue: Turkishness and Its Discontents, $\mathrm{n}^{\circ} 45$, pp. 49-73. URL: http:// research.sabanciuniv.edu/18819/

Öncü, Ayșe (2010) “Narratives of Istanbul's Ottoman Heritage”, in Diamandouros, Nikiforos; Dragonas, Thalia; Keyder, Çağlar (eds), Spatial Conceptions of the Nation: Modernizing Geographies in Greece and Turkey, London / New York, I.B. Tauris, pp. 205-228.

Öncü, Ayşe (2007) “The Politics of Istanbul's Ottoman Heritage in the Era of Globalism. Refractions through the Prism of a Theme Park", in Drieskens, Barbara; Mermier, Franck; Wimmen, Heiko (eds). Cities of the south: citizenship and exclusion in the 21st century, London, Saqi / Heinrich Böll Foundation / Institut Français du Proche-Orient, pp. 233-264. URL: http:// research.sabanciuniv.edu/9395/

Öztürkmen, Arzu (2002) “I dance folklore”, in Kandiyoti, Deniz; Saktanber, Ayşe (eds.), Fragments of Culture: The Everyday Life of Turkey. London / New York, I.B. Tauris, 2002, pp. 128-146.

Öztürkmen, Arzu (1998) Türkiye'de Folklor ve Milliyetçilik, Istanbul, İletişim Yayınları.

Öztürkmen, Arzu (1994) “The role of people's houses in the making of national culture in Turkey”, New Perspectives on Turkey, 11, pp. 159-181.

Özyürek, Esra (ed.) (2007) Politics of Public Memory in Turkey, Syracuse Univ. Press.

Pérouse, Jean-François (2014) “Hybristanbul: Turkey's urban development boom” (trans. by Victoria Lazar Graham), Books \& Ideas, 3 February 2014. URL: http://www.booksandideas.net/ Hybristanbul-2560.html

Pérouse, Jean-François (2011) « Du régime unique national de production patrimoniale au régime néo-libéral, conservateur et partiellement "pluriel" : la Turquie à l'épreuve de la transition patrimoniale », paper presented at the workshop « La gouvernance dans les politiques et pratiques patrimoniales ", within the conference cycle « Acteurs et conflits de mémoire autour du patrimoine urbain ", Juin 2011, MSH-Paris Nord, URL: http://f.hypotheses.org/wp-content/ blogs.dir/450/files/2011/08/resume-Perouse1.pdf.

Pérouse, Jean-François (2004), La Turquie en marche, Paris, Éd. De La Martinière.

Pérouse, Jean-François (2003) "La muraille d'Istanbul ou l'impossible mémoire urbaine", Rives nord-méditerranéennes, $\mathrm{n}^{\circ}$ 16, pp. 27-44. URL: http://rives.revues.org/434

Pollak, Michael (1993) "Mémoire, oubli, silence”, in Pollak, Michael Une identité blessée. Études de sociologie et d'histoire, Paris, Métailié.

Polo, Jean-François; Üstel, Füsun (2014) “Les nouvelles orientations de la politique culturelle turque sous l'AKP : néo-libéralisme et néo-ottomanisme?”, Pôle Sud, nº 41, pp. 17-32.

Poulot, Dominique (ed.) (2006) "De la raison patrimoniale aux mondes du patrimoine", Socioanthropologie, $\mathrm{n}^{\circ} 19$, pp. 3-16. URL: http://socio-anthropologie.revues.org/753

Poulot, Dominique (2004) "Histoire de la raison patrimoniale en Europe, XVIIIème - XXIème siècles”, research paper, URL: http://www.iiac.cnrs.fr/lahic/article26.html 
Rautenberg, Michel (2007-2008) "La place des artistes dans la construction de l'imaginaire patrimonial", Culture et Recherche, $\mathrm{n}^{\circ}$ 114-115, pp. 46-47.

Rautenberg, Michel (2003) La rupture patrimoniale, Aubemas, À la croisée.

Rautenberg, Michel (1998) “L'émergence patrimoniale de l'ethnologie : entre mémoire et politiques publiques”, in Poulot, Dominique (ed.) Patrimoine et modernité, Paris, L'Harmattan, pp. 279-289.

Revel, Jacques (ed.) (1996) Jeux d'échelles. La micro-analyse à l'expérience, Paris, Gallimard-Le Seuil. Roncayolo, Marcel (2011) Lectures de villes. Formes et temps, Marseille, Éditions Parenthèses.

Sauner-Leroy, Marie-Hélène (2000) "La cuisine ottomane, ou la transmission d'un art de vivre" La Pensée de midi, $\mathrm{n}^{\circ}$ 3, pp. 45-51 URL: www.cairn.info/revue-la-pensee-de-midi-2000-3page-45.htm.

Sauner-Nebioğlu, Marie-Hélène (1995) Évolutions des pratiques alimentaires en Turquie : analyse comparative, Berlin, Klaus Schwarz Verlag.

Scalbert-Yücel, Clémence (2009) “The Invention of a Tradition: Diyarbakır Dengbêj Project”, The European Journal of Turkish Studies, 10, URL: http://ejts.revues.org/4055

Scalbert-Yücel, Clémence (2005) “Conflit linguistique et champ littéraire kurde en Turquie”, doctoral dissertation, Paris, Paris IV University.

Şeni, Nora (2010) “La tentative néo-ottomane et la rénovation du quartier de la Süleymaniye", Urbanisme, $\mathrm{n}^{\circ} 374$, pp. 41-42.

Yerasimos Stéphane (2005), “Tanzimattan Günümüze Türkiye'de Kültürel Mirası Koruma Söylemi”, İstanbul Dergisi, Temmuz 2005, nº 54.

Yılmaz, Seçil (2005) Visualization of culture, history and memory in Turkey: museum politics in the post-1980s, Master of Arts, Istanbul, Boğaziçi University.

\section{NOTES}

1. See Pérouse (2011) for discussion of the many forms of contemporary heritage production.

2. For an overview of the various approaches prevalent within heritage research, see the works of Dominique Poulot as well as the book by Nathalie Heinich (2009).

3. Mention also needs to be to works of archaeology, such as the "Patrimoines au present" series by the Institut Français d'Etudes Anatoliennes, as well as the work by Zainab Bahrani, Zeynep Çelik, \& Edhem Eldem (2011) about archaeology in Turkey.

4. As well as the category of intangible cultural heritage-somut olmayan kültürel miras-which is also increasingly used, despite the fact that the term was greeted with astonishment by the professionals we interviewed during field studies a few years ago.

5. Reference may in particular be made to efforts to renew the historiography by researchers at the Turkish History Foundation during the 1990s (see Monceau 2006 for study of this Foundation) and the development of oral history within the discipline (Neyzi 2010).

6. We here refer to various ethnic groups in addition to those minorities legally recognised in Turkey under the Treaty of Lausanne (the Armenian and Jewish Rum (Orthodox Christian) populations). By political minorities we refer more specifically to the far left.

7. It now being perceived as a governance tool (Karaca 2009), and as an instrument for regional economic development (Polo \& Üstel, 2014). 
8. For an analytic overview of the various periods of cultural policy since the beginning of the Republic, see Polo \& Üstel's article. They distinguish between "State-centric cultural policy" during the period in which the Turkish nation was being built, then, as of the 1980s, a period of economic liberalisation, followed finally by a third period when the AKP's came to power in 2002 and the promotion of neo-Ottomanism (Polo \& Üstel, 2014).

9. Writing in this issue, Taline Ter Minassian comments on how research conducted by the Turkish History Society [Türk Tarihi Kurumu] into archaeology in Anatolia has played a role in building up the history of the Turkish nation. For a more general discussion of the role of historiography in nation-building, see Étienne Copeaux (1997).

10. The State, wishing to promote a "new national culture", "stigmatised Oriental culture, westernization being to its mind synonymous with modernization" (Pérouse 2004: 57). The "new national culture" was also based on secularity (for discussion of how this culture was built up via national historiography, see Copeaux 1997, 1999).

11. This theme is explored in greater detail in several articles in this issue (including those by Carney, Ter Minassian, and Zencirci); see too Öktem (2009), and Marcou (2012).

12. See the article by Josh Carney in this issue, in reference to the work of Öncü (2007) and Onar (2009) in particular; see too şeni (2010), Y1lmaz (2005), Bora (1999), Bartu (2001), and Pérouse (2004).

13. The "Anatolian mosaic" has been promoted since the 1990s, and tends to emphasise cultural differences (and celebrate them even), be they linguistic, religious, or "ethnic", i.e. relating to "non-Turkish" elements such as the Kurds, Armenians, Laz, Arabs, and so on. The local cultures making up the "Anatolian mosaic" thereby achieve recognition and become part and parcel of the national culture (Scalbert-Yücel 2005).

14. A dengbêj may be defined as "a reciter of romances and sagas" (Chyet 2003); see ScalbertYücel (2009) on this point.

15. See Neyzi (2010) for discussion of narrative and memory studies.

16. See too Navaro-Yashin (2013).

17. Reference could also be made to the "Panorama 1453 History Museum" in Istanbul, which is not studied in this issue.

18. Putting forward different timeframes in this way raises the issue of the various "regimes of historicity" (Hartog 2002) at work within these processes of heritagization, something which has not as yet been looked into.

19. Referring to the declaration "drawn up by a committee formed by the Chamber of Architects [...] and sent to the $4^{\text {th }}$ Conference of Architects in the Balkans". This declaration includes discussion of identity construction; the issue of heritage awareness and how to increase it; the implementation of a coherent conservation policy; and urban change and the fragility of the urban fabric (Yerasimos).

20. An instance of this would be pronouncements by the Istanbul Metropolitan Municipality art and vocational training courses - ISMEK [İstanbul Büyükşehir Belediyesi Sanat ve Meslek Eğitimi] (Girard 2010).

21. The role played by foreign research institutes could also be highlighted with regard to the relationship between the local and international and the part played by exogenous actors in the constitution of national heritage, such as the role played by the Institut français d'études anatoliennes in Istanbul as a heritagizing institution, from the works by its first director Albert Gabriel to those by Stéphane Yerasimos.

22. Listed as "Novruz, Nowrouz, Nooruz, Navruz, Nauroz, Nevruz" (http://www.unesco.org/ culture/ich/index.php?lg=en\&pg=00011\&RL=00282)

23. See Cilia Martin (2013) for a bibliography.

24. Referring to Nathalie Heinich's (2009) observations about authenticity in heritage production. 
25. In this precise case echoing "a set of stories, narratives, fictions, and images (it being understood that narratives also produce images), shared by a community or group" (Rautenberg 2007-2008: 46).

26. See too Öncü (2011) on this point in relation to the Southeastern Anatolia region.

27. The reference here is to Hobbes.

28. The history of Gezi Park, its foundation, and the contested project recently put forward (see Ter Minassian) is an example of heritage fluctuation. Equally the current state of dilapidation of the Atatürk Cultural Centre [Atatürk Kültür Merkezi], which might be considered as one of the key sites of Republican heritage (see Gümüş 2009 on this point), provides an additional example of this point.

29. Another instance would be the demolition of the Monument to Humanity in Kars and the attendant debates (see Burdy 2011).

30. See too Özlem Zerrin Biner about the case of Mardin and the usages of cosmopolitanism (Biner 2007).

\section{AUTHORS}

MURIEL GIRARD

ENSA Marseille

http://www.marseille.archi.fr/acteurs/chercheurs/girard-muriel/ 